\title{
PENSANDO O PEQUENO - ASPECTOS DA ESCRITA ENSAIISTICA NA ÉTICA E NA ESTÉTICA DE ANTON TCHEKHOV
}

\author{
Mariana da Silva Lima \\ marisilvalima@yahoo.com.br
}

Eram as pequenas coisas que mais o atraíam.

(Gershom Scholem, falando sobre seu amigo Walter

Benjamin.)

\section{PARA UM RETRATO DE ANTON TCHEKHOV - UMA INTRODUÇÃO}

"O paradoxo do ensaio é semelhante ao do retrato" - afirma Georg Lukács (1980, p. 10) em seu texto "Sobre a natureza e a forma do ensaio". Ele continua: "Em frente a uma paisagem nunca nos perguntamos se esta montanha ou aquele rio é realmente como está pintado; mas na frente de qualquer retrato a questão da semelhança sempre se nos impõe”. Para exemplificar seu raciocínio, Lukács propõe que imaginemos a seguinte situação: em frente a um retrato pintado por Velásquez, exclama-se: "Que semelhança extraordinária!" - e tem-se a impressão de que algo foi realmente dito sobre o quadro, muito embora não se tenha ideia de quem o quadro represente ou, ainda que fosse possível ter, isso pouco importasse. O que importa é que há semelhança: "os retratos realmente 
significativos nos fornecem, além de todas as outras sensações artísticas, também isto: a vida de um ser humano que já viveu de fato, forçando-nos a sentir que sua vida foi exatamente como vemos pelas linhas e cores do quadro".

Procedendo, neste ponto, como um bom ensaísta, logo a seguir Lukács questiona a ideia que acabou de sustentar, pois ainda que conheçamos a pessoa representada - cujo retrato podemos chamar de semelhante ou não -, seria uma abstração dizer que um momento ou expressão arbitrariamente escolhidos representam a pessoa com fidelidade. "E ainda que conheçamos milhares de tais momentos ou expressões", ele pergunta, "o que sabemos da enorme e imensurável parte de sua vida em que não a vemos, o que sabemos da luz interior que brilha nesta pessoa 'conhecida', e do modo como esta luz interior é refletida nos outros?". No entanto, é nesta abstração que, para Lukács, o ensaio se assemelha ao retrato: também no ensaio "há luta por uma verdade, pela encarnação de uma vida que alguém viu em um homem, uma época ou uma forma; mas depende apenas da intensidade do trabalho e de sua visão se o texto nos transmite esta sugestão daquela vida particular".

Esta comparação parece se aplicar com bastante propriedade a um ensaio de Thomas Mann sobre Anton Tchekhov (1860-1904). Neste texto, Mann, por assim dizer, pinta um retrato "realmente significativo" do contista russo. É possível que o retrato que vemos ali exista somente para Mann; no entanto, é um belo retrato, e é por ele que começarei este ensaio.

As fotografias [de Anton Tchekhov] mostram um homem esbelto, num traje do final do século XIX, com colarinho engomado, com pincenê preso a um cordão, barbicha pontuda e feições bem simétricas mas sofridas, cheias de amável melancolia. Estas feições exprimem uma atenção inteligente, modéstia, ceticismo e bondade. É o rosto, a atitude de um homem que não faz alarido de si mesmo. (MANN, 1988, p. 56)

Assim Thomas Mann descreve as fotografias de Tchekhov. Da descrição da fisionomia do autor russo, Mann destaca algumas atitudes do escritor, como sofrimento e melancolia. Acredito que seja razoável supor que Mann não inferiu estas características da simples contemplação de suas fotografias; pelo contrário, conforme a leitura de seu ensaio dá a entender, foi por possuir um conhecimento prévio de Tchekhov e de suas características (ou daquilo que acreditava serem Tchekhov e suas características) que Thomas Mann pôde pontuá-las em suas fotografias. Seu texto, então, apresenta sua visão sobre o escritor russo e sua obra e, embora seja um ensaio terno e tocante, não vamos aqui simplesmente 
percorrer o mesmo caminho do texto de Mann, pois a proposta deste ensaio é tentar perceber alguns aspectos da escrita ensaística na obra de Tchekhov. Tal relação foi sugerida, inicialmente, pela leitura deste texto de Mann - embora ele mesmo não chegue a formular esta hipótese. Em seu texto, Mann descreve como as atitudes de Tchekhov perante a arte e perante a vida estão intimamente ligadas. Declarando se interessar por "estabelecer uma relação entre a ascensão à mestria da forma e o aumento de uma sensibilidade moral-crítica da época, ou seja: uma relação, (...), do estético e do ético", Mann (1988, p. 52) observa como alguns dados biográficos do autor russo refletem certas atitudes suas e como estas, por sua vez, se apresentam em sua obra. Citem-se, por hora, a aversão a certezas inabaláveis, a observação do cotidiano, a incapacidade ou a desobrigação de apresentar uma ideia geral e definitiva em seus textos (confiando que o leitor vá completar o que falta à narrativa), o ceticismo e a defesa de uma moral do trabalho que "penetra nos escritos do jovem Tchekhov e de modo involuntário os eleva moralmente" (MANN, 1988, p. 52). A certa altura, Mann escreve que "a longa subestimação de Tchekhov na Europa Ocidental e até na Rússia tem muito a ver com a sua atitude sóbria, crítica e cética para consigo mesmo, com a insatisfação com que encara sua obra, numa palavra, com a sua modéstia, (...)" (MANN, 1988, p. 42). Este trecho remete diretamente a uma passagem do já citado texto de Lukács (apud ADORNO, 1973, p. 173-4), que salienta esta mesma característica ao escrever sobre "a certeira designação" de ensaios atribuída por Montaigne a seus escritos:

\footnotetext{
Pois a modéstia simples dessa palavra é uma orgulhosa cortesia. O ensaísta se desfaz das próprias esperanças, cheias de vaidade, de que às vezes se tenha chegado perto de algo definitivo: afinal, são apenas explicações de poemas de outros o que ele pode oferecer e, na melhor das hipóteses, explicações sobre os seus próprios conceitos. Mas, ironicamente, ele se sujeita a essa pequenez, à eterna pequenez da mais profunda elaboração mental frente à vida e, com irônica modéstia, ainda a sublinha.
}

Além deste ponto de contato, é possível pensar em diversas outras relações entre certos aspectos da obra de Tchekhov destacados no ensaio de Mann e os textos de Adorno ("O Ensaio como Forma”) e de Lukács sobre o ensaio, como por exemplo a posição secundária a que foram relegados, de um lado, o ensaio - justamente por ser uma formulação secundária no tempo, a respeito de objetos preformados culturalmente, como afirma Adorno em seu texto - e, de outro, a obra de Tchekhov - em parte devido a sua própria postura ante si mesmo. Além disso, a referência a Montaigne leva à reflexão sobre outros possíveis pontos 
de aproximação entre estes dois autores - e por extensão, entre suas respectivas obras, ainda que pertençam a gêneros distintos.

O ponto de partida de Mann é a morte de Anton Tchekhov (o texto foi escrito a propósito do $5^{0}$. . aniversário de seu falecimento). Ele tece algumas considerações a respeito, concluindo que os "necrológios foram provavelmente testemunhos da mesma ignorância que marcou minha própria relação com a vida e a obra deste autor, e que só no decorrer dos anos se aclarou lentamente" (MANN, 1988, p. 41). Neste trecho se insinua uma ligação entre a vida e a obra de Tchekhov, e é com base neste vínculo que Mann estrutura seu texto. Tal relação será considerada, ainda que a análise feita aqui pretenda se basear principalmente na obra de Tchekhov - a ligação que interessa, nunca é demais repetir, é entre os princípios da escrita ensaística e a obra do autor.

Tais princípios são evidenciados sobretudo quando Mann explica os motivos de seu interesse tardio pela obra de Tchekhov. Thomas Mann (1988, p. 41) evoca a sua "fascinação pela 'grande obra', pelo 'longo fôlego', pelo monumento épico perseverado e concluído numa paciência impressionante" como a razão pela qual apenas posteriormente ele manifestou interesse pela obra do escritor russo. Mann (1988, p. 42) declara que sua admiração pela "grande obra" se opunha à "forma pequena", e afirma:

\begin{abstract}
Eu nutria um certo menosprezo por essa forma, sem realmente compreender que forças íntimas de gênio eram necessárias a fim de obter o curto e o conciso, em que concisão - talvez a mais admirável - se podia absorver toda a plenitude da vida, elevar-se inteiramente à categoria épica, que bem pode superar em intensidade artística o grande, a obra gigantesca que, às vezes, inevitavelmente fica cansativa e monótona.
\end{abstract}

De fato, como afirma Thomas Mann em outra passagem, Tchekhov era um "homem da forma pequena". Seja na predileção por temas banais e personagens muitas vezes tidos como "insignificantes", seja na intensa dedicação à breve forma literária do conto, sua obra parece inscrever-se sob o signo do pequeno ${ }^{1}$. Ele manifestou diversas vezes sua vontade de

1 Após a primeira redação deste ensaio, tomei conhecimento do livro The pragmatics of insignificance: Chekhov, Zoshchenko, Gogol, no qual a autora Cathy Popkin explora este paradoxo presente em obras literárias canônicas e "grandiosas" que tratam de assuntos banais analisando-o sob o binômio trivialidade e narratividade ("triviality and tellability"). No caso de Tchekhov, a autora argumenta que "sua seleção de assuntos ostensivamente triviais não é acidental, mas antes um princípio deliberado de construção narrativa; ademais, que ele procede desse modo não desconsiderando a importante dis- 
escrever romances, e o fato de que nunca chegou a redigir nenhum talvez tenha a ver com essa sensibilidade para o diminuto, para as coisas que em geral passam despercebidas.

Embora a ficção e o ensaio constituam duas formas de escrita relativamente diferentes - uma de ordem imaginativa, e estritamente artística, e outra, teoricamente não ficcional, e de certo modo híbrida entre a artística e a científica ou filosófica (não se pretendendo aqui aprofundar na discussão que Lukács desenvolve no texto "Sobre a natureza e a forma do ensaio" a respeito da natureza artística ou científica do ensaio, mas apenas diferenciando o âmbito de criação do ensaio) -, essa oposição ao grandioso parece estar presente tanto na obra de Tchekhov quanto no gênero ensaístico. Proponho explorar essa relação a partir de uma novela de Tchekhov que acredito ser exemplar de sua dedicação à "forma pequena".

\section{ENSAIANDO UMA HISTÓRIA ENFADONHA}

Entre as mais belas narrativas de Tchekhov, há uma curiosamente intitulada "Uma história enfadonha - Das memórias de um homem idoso" (1889). O título chama atenção porque, ao qualificar sua história como enfadonha, Tchekhov motiva uma disposição desagradável no leitor: é como se ele nos advertisse que o assunto será aborrecido e cansativo. Logo de início a novela aponta a falta de interesse que pode suscitar, e eis aqui um primeiro paradoxo deste texto: a narrativa desperta interesse exatamente por ser qualificada como desinteressante. Efeito muito semelhante a esse foi obtido por Montaigne na advertência com a qual abre seus Ensaios: "Assim, leitor, sou eu mesmo a matéria deste livro, o que será talvez razão suficiente para que não empregues teus lazeres em assunto tão fútil e de tão mínima importância."

Cabe nos questionarmos sobre o motivo dessas advertências. Com que propósito estes escritores, ao invés de recorrer a estratégias para seduzir o leitor, tentam, ao contrário, impedi-lo mesmo de começar a ler, ao chamar sua atenção para o aspecto maçante e desimportante de seus textos? Ou, inversamente, não constituiria esse método um meio

tinção entre temas significativos e insignificantes, mas com uma profunda preocupação com essas categorias, preocupação que é passada ao leitor; e finalmente, que os textos daí resultantes, longe de serem indiferentes, são sutil mas intensamente críticos" (POPKIN, 1993, p. 23). 
ardiloso para captar a atenção do leitor? Qual a atitude por trás deste procedimento?

Aquela primeira impressão negativa provocada pelo título da novela de Tchekhov é negada logo em seguida, pois o personagem apresentado pelo narrador parece ter relativa importância em seu país: "Vive na Rússia o emérito Professor Nicolai Stiepánovitch de Tal, conselheiro privado; ele possui tantas condecorações russas e estrangeiras que, nas ocasiões em que precisa usá-las, os estudantes chamam-no de iconóstase" (TCHEKHOV, 1982, p. 239). O narrador inicia o texto listando os títulos do personagem; ora, não se trata aqui de um João ninguém; estamos falando de um profissional reconhecido. Assim, àquela primeira tensão entre a informação introduzida pelo título - de que o texto seria desinteressante - e uma possível reação provocada por ela - interesse -, segue-se outra: se o título indicava um personagem enfadonho, o narrador da novela apresenta o personagem como um homem célebre, portador de diversos títulos nacionais e estrangeiros, o emérito Professor Nicolai Stiepánovitch... de quê mesmo? De Tal. Como assim, de Tal? Um Nicolai Stiepánovitch qualquer? Ou o emérito Professor, tão distinto e condecorado que, quando precisa usar todas as suas medalhas, é chamado por seus alunos de iconóstase (espécie de biombo coberto de ícones usado nas igrejas da religião ortodoxa)? O "tal" remete, então, novamente ao "enfadonho" do título.

Essas contradições, longe de serem resolvidas, são cada vez mais exploradas no texto. A novela tem início com uma série de tensões que se mantêm ao longo de toda a narrativa. É o que demonstra esta outra passagem da abertura: "É membro de todas as universidades russas e de três estrangeiras. Etcétera e etcétera". O "tal” e o "etcétera" talvez apontem para um desinteresse do próprio narrador, insinuando, assim, mais uma vez, que a história será enfadonha.

Como se essas tensões não fossem suficientes, Tchekhov problematiza também o ponto de vista da narrativa, pois, se a novela começa na terceira pessoa, ao fim do primeiro parágrafo o narrador se identifica como o personagem sobre o qual falava. "Tudo isso e muito mais que se poderia dizer constitui o que se chama o meu nome." A partir deste ponto, Nicolai assume a narrativa em primeira pessoa - é como se o narrador escrevesse: "sou eu mesmo a matéria deste conto" - aliás, a matéria enfadonha deste conto.

Portanto, deste modo, o leitor fica ciente de que constituem um mesmo personagem o narrador e o homem idoso do subtítulo, do qual irá ler as memórias. Estas, como vimos, têm início com uma apresentação dos diversos títulos que possui o personagem. Nicolai retoma o inventário 
de suas glórias ao descrever o que constitui o seu nome: "Pois o meu nome está intimamente ligado à noção de homem famoso, ricamente dotado e indiscutivelmente útil. Sou trabalhador e resistente como um camelo, e isso é importante, bem como talentoso, o que é mais importante ainda" (TCHEKHOV, 1982, p. 239). Essa atitude demonstra um comportamento detidamente analisado por Montaigne (1972, p. 295) no ensaio "Da presunção", em que descreve a característica do título como um tipo de glória "que consiste em termos opinião demasiado boa de nós mesmos", fazendo com que "nos representemos aos nossos próprios olhos diferentes do que somos".

Porém, esse deslumbramento que Nicolai demonstra por si próprio, e que o cega por momentos para suas características pessoais, fazendo com que ele as veja como que por uma lente de aumento, esse fascínio pela própria imagem constitui uma atitude que foi duramente criticada por Tchekhov, como podemos ver em suas cartas. Daí que logo se percebe o truque do narrador ao dividir o nome e a persona de Nicolai Stiepánovitch nas páginas iniciais da novela. Pois há uma curiosa divisão entre o eu na descrição que o personagem faz de si mesmo, entre a imagem correntemente associada ao nome do personagem, e o que seria o personagem propriamente dito. Aliás, essa separação toma ares absurdos quando o narrador escreve: "Em geral, o meu nome científico não tem qualquer mácula, nem do que se queixar. Ele é feliz”. O personagem realiza assim uma transição absurda ao dizer que seu nome científico não tem qualquer mancha - assertiva totalmente verossímil -, completando que ele - seu nome - não tem do que se queixar. O narrador atribui assim a algo inanimado - um nome - características humanas - a possibilidade de se queixar e de ser feliz. Deste modo, efetua uma separação radical entre o que seria a aparência do personagem e sua essência. Também Montaigne (1972, p. 459) observou a cisão entre sua personalidade pública e particular no ensaio intitulado "Do domínio da própria vontade":

A maior parte das funções públicas tem algo de cômico, 'todos representam', dizia Petrônio. Cumpre desempenhar devidamente seu papel, mas sem transformar a máscara e a aparência em realidade nem deixar que o estranho se encarne em nós. (...) Basta enfarinhar o rosto, não é preciso mascarar igualmente o peito. Há quem mude e se transforme em outro ser segundo o cargo que assume; neste mergulham até o fígado e os intestinos e mesmo na privada agem como se estivessem no exercício de suas funções. (...) Montaigne prefeito e Montaigne simples particular sempre foram homens distintos, e nitidamente distintos. Não é por ser advogado ou financista que se há de ignorar o que tais profissões comportam de velhacaria; um homem de bem não é responsável pelos vícios ou tolices de seu ofício e não deve por isso recusar-se a exercê-lo. (...) É preciso viver no mundo e do mundo. Mas o juízo 
de um imperador deve pairar acima de seu império, o qual ele deve encarar como um acidente alheio a si mesmo; e sua pessoa deve gozar de si própria à margem das suas funções e cumpre-lhe entreter-se consigo mesmo tal como o faria Pedro ou João.

Daí se conclui que esta divisão entre o eu enunciador e o eu representado (ou enunciado) presente em "Uma história enfadonha" obedece a necessidades específicas da própria narrativa, pois quando separa o nome do personagem, Tchekhov (1982, p. 239) cria uma oportunidade para ridicularizar aquela atitude prepotente que Nicolai demonstra ao associar seu nome científico "à noção de homem famoso, ricamente dotado e indiscutivelmente útil". Portanto, ao descolar esta atitude do personagem, o narrador - ou seja, o próprio personagem - se distancia de si mesmo; assim, ele pode se ver mais claramente. E o que ele vê é o abismo que separa seu nome de si mesmo: "O dono desse nome, isto é, eu, representa um homem de sessenta e dois anos, calvo, com dentadura postiça e tique incurável. Na mesma medida em que o nome é belo e brilhante, sou pessoalmente apagado e disforme" (TCHEKHOV, 1982, p. 240).

E assim, aos poucos a narrativa vai tomando ares de confissão. $\mathrm{O}$ personagem que a princípio inventariava seus títulos - mas inventariava de tal modo que era como se inventariasse os títulos de um outro, já que, nesse momento, falava de si mesmo em terceira pessoa; logo, nesse momento, era o narrador de si mesmo -, agora apresenta uma lista interminável de defeitos seus, de modo semelhante ao que lemos no ensaio "Da presunção", de Montaigne (1972, p. 304):

Que me confesse um pouco mais e verão quantas coisas me faltam. Pouco importa. O que importa é que eu me mostre tal qual sou; não me desculpo portanto por ousar escrever acerca de coisas tão vulgares, tão desinteressantes: a banalidade de meu assunto a isso me obriga. Critiquem se quiserem a ideia de fazê-lo, mas não o método seguido. É certo ainda que não precisam advertir-me da insignificância do que digo; sei por mim mesmo que não vale grande coisa e quanto é absurda minha ambição.

Deste modo, tanto os Ensaios de Montaigne quanto a novela de Tchekhov em questão têm um caráter confessional, uma vez que ambos os "narradores" (considerando ser possível atribuir tal termo a Montaigne) declaram seus defeitos. Este aspecto autorreflexivo também se evidencia no caráter de memórias que assumem, de um lado os Ensaios de Montaigne, e de outro, a novela de Tchekhov. Pois se o próprio subtítulo da narrativa - "Das memórias de um homem idoso" - 
indica tal característica, ela também está presente na obra de Montaigne. No ensaio intitulado "Da vaidade", Montaigne (1972, p. 447) escreve: "Na medida do possível, aqui revelo minhas ideias e afeições e as revelaria mais livremente de viva-voz a quem as desejasse conhecer. Não obstante, ver-se-á que nestas memórias tudo disse e indiquei; e o que não pude expressar aponto-o com o dedo".

Parece propício fazer aqui uma pausa para analisar em que medida é possível falar na presença de um narrador nos Ensaios de Montaigne, isto é, em que medida seus textos são "contaminados" pela prosa de ficção. Em seu livro dedicado a Montaigne, Peter Burke remete ao contexto histórico do ensaísta francês para determinar o modo como seus escritos foram se diferenciando da produção textual da época. Ele informa que "a ideia de publicar um conjunto de discursos sobre assuntos variados em um único volume não era nova nos tempos de Montaigne" (BURKE, 1985, p. 82), e uma vez que muitos de seus trabalhos iniciais constituem um mosaico de citações dos autores clássicos, ele conclui que os ensaios parecem ter surgido de uma prática comum do século XVI de se fazer "almanaques" de frases memoráveis. Entretanto, Burke observa que Montaigne "foi prestando cada vez menos atenção às citações que havia reunido, e cada vez mais a suas próprias reações e reflexões". Se, por um lado, o ensaio guarda traços de alguns gêneros cultivados na época em que Montaigne escrevia, como a carta, o solilóquio e o paradoxo, por outro, ele manifesta uma forma própria na medida em que o autor manifesta a intenção de "captar-se a si mesmo no ato de pensar, oferecendo antes o processo do pensamento do que suas conclusões" (BURKE, 1985, p. 83). Porém, este retrato que o autor pinta de si mesmo resulta em uma criação fictícia, como assinala o próprio Montaigne (1972, p. 309): "Pintando-me para outrem, pintei-me em cores mais nítidas do que eram minhas cores originais. Eu não fiz mais o meu livro do que o meu livro me fez". Por isso Peter Burke (1985, p. 85) afirma que "o 'Eu' dos ensaios - que poderíamos chamar 'Michel' - é um artifício literário tanto quanto o 'Marcel' de Proust". É neste sentido que se refere aqui à presença de uma voz narrativa nos ensaios de Montaigne: ao se pintar com cores mais nítidas do que as originais, Montaigne, de certo modo, cria o personagem Michel, e na voz que descreve este Michel fictício podemos identificar traços de uma voz narrativa.

A autorreflexão presente na novela e no ensaio sugere inclusive uma semelhança formal entre os dois textos. Curiosamente, ambos os narradores não só apresentam características semelhantes como também refletem sobre elas no decorrer de seus textos. Comentando sua própria 
redação, Nicolai Stiepánovitch resume que escreve mal. O personagem/ narrador explica:

\begin{abstract}
Minha memória enfraqueceu, os pensamentos não têm a necessária continuidade, e, quando os exponho no papel, vem-me cada vez a impressão de ter perdido o sentido da sua ligação orgânica, a construção é monótona, a frase, tímida e avara. Muitas vezes, não escrevo o que quero; quando escrevo o fim, já esqueci o princípio. (TCHEKHOV, 1982, p. 240)
\end{abstract}

Uma vez que Nicolai se assume como narrador de suas memórias, seria de se esperar que a novela apresentasse os traços acima referidos. De fato, "Uma história enfadonha" apresenta algumas das características supracitadas, como uma ligação fragmentária e desnecessária entre os incidentes narrados e uma grande incidência de digressões. Mencionese como exemplo os inúmeros parágrafos dedicados à descrição da entediante rotina do professor ou de noites insones, os quais constituem episódios que poderiam ser suprimidos sem causar dano potencial à fábula da narrativa. No entanto, o próprio Tchekhov (apud ANGELIDES, 1995, p. 150) assinalou, em uma carta, a importância de tais passagens para a construção do enredo: "Nele [no conto], o mais enfadonho, como você verá, são as longas reflexões, que infelizmente não podem ser suprimidas, pois o meu herói, autor das memórias, não consegue passar sem elas. Essas reflexões são fatais e necessárias, como a carreta pesada é necessária para um canhão". Logo, se estas reflexões não acrescentam nenhum dado do ponto de vista dos acontecimentos, elas fornecem uma informação importante em relação à forma da narrativa. Elas caracterizam não tanto os estados de espírito do protagonista (como indicou Tchekhov naquela mesma carta), mas a forma de seu pensamento. E isso se aplica tanto às reflexões do personagem quanto às descrições de suas noites insones, porque, em última instância, tanto umas quanto outras constituem estratégias do narrador.

As características citadas por Nicolai também são mencionadas por Montaigne em relação ao modo como escreve. E assim como aquele, Montaigne (1972, p. 298) não parece fazer questão de esconder ou de disfarçar seu método, mas antes o sublinha e não tem escrúpulos em apresentá-lo negativamente: "Minha linguagem nada tem de fácil e fluida; é antes áspera, livre, desregrada. (...) Por mais que tentasse tornar a minha igual, uniforme, bem ordenada, não o conseguiria”. E, algumas linhas antes, Montaigne assim descreve o seu estilo - "se é que posso chamar estilo a uma linguagem informe, desobediente a todas as regras, verdadeiro jargão popular, unida a uma redação inominável, mal equilibrada, falta de clareza e inconclusiva". 
A ligação intrínseca entre tema e forma perceptível na novela de Tchekhov e nos Ensaios de Montaigne não é gratuita. Se este recorre a uma forma livre e a assuntos banais para expressar suas ideias, é justamente porque assim se evidencia melhor sua visão de mundo. Pelo mesmo motivo, Tchekhov fragmenta o fio narrativo e abusa de incidentes menores. Ambos os autores recorrem a artifícios semelhantes não para ilustrar didaticamente uma visão de mundo, mas pelo fato de estes textos estarem impregnados de uma visão de mundo semelhante. Se suas formas são livres e não cabem em nenhuma forma, é porque assim é o pensamento daqueles que os conceberam.

Há, entretanto, uma ressalva a ser feita. Comentando esta narrativa com seu amigo e editor Alekséi Suvórin, Tchekhov (apud ANGELIDES, 1995, p. 155) escreveu: "Na novela inteira há apenas um pensamento que eu compartilho, e ele está na cabeça do genro do professor, (...); é o seguinte: 'O velho perdeu o juízo!' Todo o resto é inventado e fabricado". Apesar dessa observação, contudo, muitas das opiniões emitidas pelo narrador da novela se aproximam de ideias expressas pelo autor em cartas, e por isso sustentam as comparações.

Logo, o que poderia parecer uma relação casual ou uma coincidência, na verdade expressa um modo de ver intimamente relacionado à atitude do ensaísta. A autorreflexão seria assim um traço distintivo da escrita ensaística, que parece obedecer a determinadas regras formais cujo principal atributo é justamente o de não obedecer a regras. Os traços distintivos do gênero ensaístico são o tema do ensaio intitulado "O Ensaio como forma”, de Theodor Adorno. Uma das principais questões tratadas por Adorno (1973, p. 172) neste texto é o modo como o ensaio se opõe ao conhecimento dito científico:

Os ideais de pureza e limpeza, que são comuns a uma filosofia voltada para valores eternos, para uma ciência organizada de cima até embaixo, sem lacunas, coerente e intangível, bem como a uma arte intuitiva despida de conceitos, tais ideais trazem os traços de uma ordem repressiva. Passa-se a exigir do espírito um certificado de competência administrativa, para que ele, ao ater-se às linhas limítrofes culturalmente delineadas e sacramentadas, não vá além da própria cultura oficial. Pressupõe-se nisso que todo conhecimento possa, potencialmente, ser convertido em ciência.

Adorno argumenta que o modo de proceder do ensaio, ao suspender o conceito tradicional de método, questiona o direito incondicional das doutrinas filosóficas ou científicas que discutem as condições de conhecimento. A pretensão da ciência à verdade também foi objeto 
central de crítica por parte de Tchekhov (apud MANN, 1988, p. 42), como podemos perceber na leitura deste trecho de uma carta: "Que o diabo carregue a filosofia dos grandes deste mundo! Todos os grandes sábios são despóticos como generais e descorteses como generais, pois estão convencidos da sua impunidade". Veja-se como o professor de "Uma história enfadonha" descreve um colega de trabalho:

Outra característica: uma crença fanática na infalibilidade da ciência e, principalmente, de tudo o que escrevem os alemães. Ele está certo de si mesmo, das suas preparações anatômicas, conhece a finalidade da vida e ignora totalmente as dúvidas e decepções, que fazem embranquecer o cabelo dos homens de talento. Uma veneração servil pelas autoridades científicas e ausência da necessidade de pensar por si. É difícil tirar-lhe alguma das convicções, discutir com ele é impossível. Experimente discutir com um homem profundamente convicto de que a medicina é a melhor das ciências, os médicos os melhores homens, e as tradições médicas, as melhores existentes. Apenas uma tradição subsiste do infausto passado da medicina: a gravata branca que usam os nossos médicos; para o cientista e para o homem culto em geral, só podem existir tradições universitárias em bloco, sem qualquer divisão em medicinais, jurídicas, etc., mas Piotr Ignátievitch dificilmente se conforma com isso, e ele está pronto para discutir com você até o Juízo Final. (TCHEKHOV, 1982, p. 248)

Por se mostrar desconfiado em relação à qualquer pretensão à grandeza, à "filosofia dos grandes", Tchekhov revela uma atitude cética, semelhante à que Montaigne deixa entrever em seus Ensaios. No ensaio intitulado "Da presunção", Montaigne (1972, p. 296) faz coro à objeção de Tchekhov em relação a essa confiança excessiva na ciência:

A filosofia nunca se me afigura mais certa do que quando combate nossa presunção e nossa vaidade, quando reconhece de boa fé sua ignorância e sua fraqueza. Parece-me que a origem dos maiores erros do nosso julgamento, tanto do indivíduo como da massa, e o que os mantém vivos, é a opinião demasiado favorável que o homem tem de si. Esses sujeitos que cavalgam a órbita de Mercúrio e veem tão claramente o que ocorre no céu, fazem-me dar de ombros.

Esse trecho nos remete de volta à novela. "Uma história enfadonha" é a estória da descoberta da presunção de um homem, da ruína das certezas desse professor de medicina outrora tão confiante na ciência e em si mesmo. Quanto mais Nicolai se analisa, mais ele se dá conta do malogro pelo qual se deixou enganar. De modo semelhante, o ensaio se posiciona ceticamente diante da pretensão da ciência de tudo definir: 
Sem apologia, assume a objeção de que é impossível saber acima de qualquer dúvida que ideia se deveria fazer dos conceitos. Pois percebe que exigir definições estritas contribui há muito tempo para eliminar, mediante a manipulação dos conceitos através de sua fixação, o elemento irritante e perigoso das coisas, que vive nos conceitos. (ADORNO, 1973, p.176)

Por isso a opção por uma escrita reflexiva, pois o ensaio precisa compensar no modo de expor o que é sacrificado em termos de precisão. Adorno (1973, p.182) escreve que o ensaio "gostaria de poder curar o pensamento de seu caráter arbitrário ao incorporá-lo reflexivamente em seu procedimento, ao invés de mascará-lo de imediatez". Pode-se perceber então de que modo essa atitude oposta à autoridade do pensamento que se quer científico determina uma forma própria de pensar, forma esta que pode se realizar na escrita ensaística. A esse respeito, Montaigne (1972, p. 296) escreve:

\begin{abstract}
Deparo, com efeito, neste meu estudo, que tem por objeto o homem, com uma tal variedade de juízos, um tal labirinto de dificuldades, tanta incerteza e indecisão entre os que ensinam a sabedoria, que se essa gente não consegue sequer conhecer-se a si mesma, nem entender as condições de sua existência, que tem continuadamente sob os olhos, que nela reside, se essa gente não sabe como se move o que ela própria põe em movimento, (...) eu, por meu lado, sinto-me pouco propenso a nela acreditar quando nos expõe as causas a que atribui o fluxo e o refluxo do Nilo. A curiosidade de tudo conhecer é um flagelo da Humanidade, rezam as Escrituras.
\end{abstract}

Assim Montaigne justifica os motivos de sua descrença no que se poderia chamar de ciência oficial e de sua objeção à tentativa de tudo conhecer, o que o leva, em contrapartida, a legitimar o conhecimento com base na experiência individual - "conhece-te a ti mesmo". O preceito socrático também é almejado pelo narrador da novela de Tchekhov, ainda que com certa ironia: "Quando amanhece, estou sentado na cama, abraçando os joelhos, e, não tendo o que fazer, procuro conhecer a mim mesmo. 'Conhece-te a ti mesmo' - eis um belo e útil conselho; dá pena, porém que os antigos não tenham adivinhado como indicar o meio de utilizá-lo". Esse apelo a conhecer-se a si mesmo, que tanto fazem Nicolai como Montaigne, relaciona-se à validação do conhecimento baseado na experiência individual e, estilisticamente, realiza-se na forma de uma escrita autorreflexiva. Em relação à superioridade do conhecimento especulativo sobre o conhecimento científico, Adorno (1973, p. 186) observa que "a silenciosa docilidade do curso dos pensamentos do ensaísta obriga-o a uma intensidade maior que a do pensamento discursivo, pois 
o ensaio não procede, como aquele, de um modo cego e automatizado, mas a todo momento precisa refletir sobre si mesmo". Segundo Adorno, o pensamento discursivo, adotado como única possibilidade pela ciência, estaria relacionado às regras que Descartes institui no Discurso sobre o método, enquanto o pensamento autorreflexivo estaria associado justamente ao modo de proceder do ensaio. Adorno (1973, p. 177) diz que o ensaio "deveria ser interpretado como um protesto contra as quatro regras que o Discours de la méthode de Descartes erige no início da moderna ciência ocidental e de sua teoria”, por desafiar os ideais da percepção clara e distinta e o da certeza livre de dúvida².

Em relação à terceira regra cartesiana, a qual estabelece a ordem e a gradação, Adorno (1973, p. 175) escreve que o ensaio "abandona a rota militar na direção das origens": "Ele não começa com Adão e Eva, mas

2 É curioso notar que o questionamento que levou Descartes à elaboração de regras que orientassem o método científico surgiu de uma interrogação inicial semelhante à descrita por Montaigne. Tanto Descartes quanto Montaigne manifestaram uma incerteza em relação ao conhecimento científico, isto é, ambos partiram de um questionamento inicial sobre como ter certeza de que as ciências estariam no caminho da verdade. Na busca de um princípio que fundamentasse a razão, ambos utilizaram a dúvida como método de investigação filosófica. Para alcançar a verdade, Descartes formula o ceticismo sistematicamente - ou seja, para eliminar toda e qualquer dúvida, seria preciso duvidar de tudo. Na tentativa de verificar a existência de algo de que não pudesse duvidar, Descartes põe tudo em dúvida - inclusive o pensamento: "Por desejar ocupar-me somente com a pesquisa da verdade, pensei ser necessário (...) rejeitar como absolutamente falso tudo aquilo em que pudesse imaginar a menor dúvida, a fim de ver se, após isso, não restaria algo em meu crédito que fosse inteiramente indubitável".

Mas daí decorre uma certeza: a de que o pensamento duvida. Se, mesmo ao duvidar de que duvida, ele continua duvidando, Descartes conclui que deve existir algo que duvida: o pensamento (dubito, ergo cogito; cogito, ergo sum). Ele resume na fórmula "penso, logo existo" a constatação de uma certeza inabalável. Partindo desta confiança agora depositada na razão, Descartes busca estabelecer os princípios que garantiriam a segura condução do pensamento. Tratar-se-ia de fornecer, a todas as ciências, um fundamento único e comum que garantiria seu acesso à verdade. Assim ele formula as regras cuja função seria a de fixar "os procedimentos que todas as investigações científicas devem seguir": a regra da evidência (que estabelece que só é verdadeiro o que é evidente, ou seja, o que se pode intuir com clareza e precisão), a da análise (que se relaciona à divisão de "cada uma das dificuldades em tantas parcelas quantas sejam necessárias para serem resolvidas"), a da síntese (relacionada à condução ordenada e gradativa dos pensamentos, dos mais simples para os mais complexos) e a da enumeração (que determina a realização de enumerações "de modo a verificar que nada foi omitido").

Assim, partindo de uma mesma dúvida inicial sobre a segurança do saber, Descartes e Montaigne chegam a campos opostos: enquanto Descartes supera aquela desconfiança inicial em relação à razão humana, Montaigne a sustenta; enquanto o primeiro deposita confiança ilimitada na razão, o outro crê que, em se tratando de razão humana, é impossível chegar a um juízo absoluto. 
com aquilo de que quer falar; diz o que lhe ocorre, termina onde ele mesmo acha que acabou e não onde nada mais resta a dizer: assim ele se insere entre os despropósitos" (ADORNO, 1973, p. 168). Sobre sua falta de método, Montaigne anota: "Cícero reconhece que nas questões filosóficas o mais difícil é a entrada em matéria. Talvez por isso mesmo passo logo prudentemente à conclusão". Diversos ensaios de Montaigne têm início com uma sentença conclusiva. Sua despreocupação com a ordem dos argumentos também se expressa no emprego frequente de digressões. Na obra de Tchekhov, esse aspecto se evidencia principalmente na ausência de clímax e de conclusão de seus contos. A esse respeito, Virginia Woolf (1966, p. 108-9) observa, ao comentar um conto de Tchekhov intitulado "Gusev":

A ênfase é colocada em lugares tão inesperados, que inicialmente não parece haver nenhuma ênfase; depois, assim como os olhos se acostumam a discernir o formato das coisas num quarto em penumbra, acabamos vendo como a história é completa, profunda e como, em perfeita obediência à sua visão, Tchekhov escolheu isto, aquilo e mais aquilo, fazendo disso um todo para compor algo novo. Mas é impossível dizer "isto é cômico" ou "aquilo é trágico"; e como nos ensinaram que um conto deve ser breve e ter conclusão, não temos certeza se esse, que é vago e não tem conclusão, deve ser chamado de conto.

Como bem lembra Boris Schnaiderman (1999, p. 335), o deslocamento da ênfase para locais inesperados e o não-desfecho não chegam a se constituir como características absolutas da narrativa tchekhoviana, havendo contos, tais como "Volódia", em que "tudo converge para um final forte”. Na correspondência de Tchekhov, é frequente encontrarmos passagens em que o escritor reflete sobre o desfecho de seus contos e peças. Quanto a isso, Schnaiderman (1999, p. 336) relativiza a consciência do autor ao empregar métodos inovadores, enfatizando a "vacilação diante dos resultados novos a que chegava”. Porém, o crítico reconhece que, ainda que Tchekhov tenha hesitado ao romper com as regras estabelecidas das artes dramática e narrativa, "nem por isso os novos caminhos que ele abriu foram menos decisivos para a ficção e o teatro". Para os propósitos deste ensaio, pode-se acrescentar que, mesmo que o desfecho em aberto não seja um traço absoluto na obra de Tchekhov, ele veio a se constituir como uma das características predominantes de sua poética.

Essa irresolução de seus contos, presente nos desfechos em aberto, não se limitava, porém, ao plano da construção da narrativa, mas se estendia ao plano ideológico, na ausência de uma postura política mais explícita. 
Schnaiderman considera que, "se em relação ao possível não-desfecho, ou desfecho diferente, Tchekhov parece em sua correspondência ter momentos de dúvida, a nova hierarquia entre objetos e acontecimentos é algo bem consciente e determinado, e liga-se a toda a sua concepção de vida, à sua maneira de ver o mundo". Pois esta verdadeira "subversão do consagrado" nos âmbitos estético e ideológico provocou profunda estranheza perante a obra de Tchekhov, tanto por parte do público quanto da crítica. Sophia Angelides (1995, p. 36) explicita as razões por que o escritor era acusado de indefinição diante dos problemas colocados por sua obra remetendo ao contexto histórico do autor:

A incompreensão que Tchekhov gera nos seus contemporâneos tem raízes na tradição crítica russa que, desde a década de 186o, com o advento do populismo, avaliava a obra literária em função das ideias sociais e políticas que transmitia, relegando para um segundo plano os aspectos literários propriamente ditos.

Da parte de Tchekhov, essa escrita que desafiava as expectativas da época parece decorrer tanto de uma incapacidade pessoal quanto de uma recusa deliberada. Em carta de nove de outubro de 1888 a Dmítri Grigórovitch, Tchekhov escrevia: "Ainda não tenho uma concepção política, religiosa e filosófica do universo; mudo-a todo mês e por isso sou obrigado a me limitar apenas à descrição de como minhas personagens amam, casam-se, procriam, morrem e de como elas falam”. Contudo, apenas duas semanas mais tarde (em 27 de outubro), escreve a seu amigo Suvórin: "Ao exigir do artista uma atitude consciente em relação ao seu trabalho, você tem razão, mas confunde dois conceitos: a solução do problema e a colocação correta do problema. Apenas o segundo é obrigatório para o artista". Thomas Mann (1988, p. 49) salienta que "a pergunta 'o que fazer' aparece constantemente nos escritos de Tchekhov”, e que

A verdade da vida, à qual o escritor sempre é obrigado, deprecia as ideias e as opiniões. Ela é irônica por natureza, e facilmente leva a que o escritor, para quem a verdade é o mais importante, seja censurado pela sua falta de ponto de vista, pela indiferença ao bem e ao mal e pela falta de ideais e de ideias. (MANN, 1988, p. 51)

Thomas Mann lembra que Tchekhov confiava na capacidade do leitor de completar o que faltava na narrativa, mas mesmo assim constata uma angústia provinda da pergunta "o que fazer", à qual o escritor se via obrigado a responder "Palavra de honra, não sei”. Tchekhov temia estar 
levando o leitor "para trás da luz", pois na verdade não sabia "responder às questões mais importantes". Em sua obra, esse aspecto se verifica na medida em que as tensões não são resolvidas, mas, ao contrário, é mantida uma irresolução de posições. Em "Uma história enfadonha”, o questionamento por uma ideia que unificasse a vida do professor não só é trazido à tona por ele, mas ironizado na resposta do personagem: "Se me perguntassem: o que constitui agora o traço principal, básico, da sua existência? - eu responderia: a insônia" (TCHEKHOV, 1982, p. 240). Além disso, a dificuldade do professor em encontrar uma ideia unificadora para sua vida é amplificada na indecisão de Kátia, sua pupila, quanto ao que fazer de sua própria vida. Ela procura o professor em busca de ajuda e de orientação, mas ele também não sabe o que lhe dizer. Assim, a indecisão é tensionada ao máximo, pois Kátia abandona o professor sem resposta para sua pergunta.

Isto não significa uma ausência de postura crítica - pelo contrário. Esta pode ser verificada em Tchekhov em sua atitude para consigo mesmo, na dúvida e na insatisfação com que encarava sua obra, e que se traduziram em um autoceticismo, ou ainda, como observou Mann, em uma modéstia que "em momento algum tem pretensão de qualquer autorização de grandeza”. Deste modo, assim como o ensaio investiga as possibilidades de escrita ao pensar sobre si mesmo, ao se pôr em dúvida, ou ainda, ao se questionar, pode-se pensar em uma dimensão autorreflexiva na obra de Tchekhov, na medida em que ele olha para si mesmo ao escrever, e não só pensa seu objeto mas também o próprio ato de pensar.

Como já foi indicado, a autorreflexão como característica determinante do ensaio desdobra-se em uma investigação das possibilidades de conhecimento da consciência - ou, invertendo os termos, na medida em que questiona os limites estabelecidos à reflexão, o ensaio se realiza como uma forma de escrita autorreflexiva. Adorno (1973, p. 172) argumenta que a "mais simples reflexão sobre a vida da consciência poderia ilustrar quão pouco se pode captar, com a rede conceitual científica, conhecimentos que não são, em absoluto, meros palpites desconchavados, meras impressões desconexas". Ele remete então à obra de Marcel Proust, afirmando que, embora os conhecimentos expressos em sua obra não possam, "sem mais nem menos, ser assumidos e ultrapassados pela ciência", "a pretensão desses conhecimentos à objetividade não fica diminuída nem reduzida a uma vaga plausibilidade”; segundo Adorno, a "medida de tal objetividade não é a comprovação de teses já firmadas através de repetidas provas, mas a experiência 
humana individual mantida por esperança e desilusão". Estamos de volta, portanto, àquela oposição entre o conhecimento validado pelo saber dito científico e um conhecimento baseado na experiência humana individual - tensão que, salvo engano, constitui-se como uma das fontes da angústia do narrador da novela de Tchekhov. Sobre essa oposição, Montaigne (1972, p. 306) escreve:

Em geral, os homens voltam-se para fora; eu, volto-me para dentro de mim mesmo, demoro-me na investigação e nela me comprazo. Todos olham para a frente, ao passo que eu olho para mim, observando-me, analisando-me. Os outros, se pensam seriamente, tocam para diante: 'Ninguém tenta descer em si mesmo' (Pércio); eu paro, e fico a enredar-me no pensamento.

É também o que faz Nicolai, como o demonstra o seguinte trecho: "Quando, em outros tempos, dava-me na veneta compreender alguém ou a mim mesmo, eu examinava não as ações, em que tudo é convencionado, mas os desejos. Dize-me o que desejas, dir-te-ei quem és" (TCHEKHOV, 1982, p. 296). Logo depois, remata: "Também agora, faço um exame a mim mesmo: o que eu quero?” (TCHEKHOV, 1982, p. 297). Ao empreender esta autoanálise, Nicolai chega à seguinte conclusão:

No meu fraco pela ciência, no meu desejo de viver, neste ato de ficar sentado numa cama alheia e na ânsia de conhecer a mim mesmo, em todos os pensamentos, sentimentos e concepções, que eu formo a respeito de tudo, não existe algo geral, que una isso num todo. Cada sentimento e cada pensamento vivem em mim isolados, e em todos os meus juízos sobre a ciência, o teatro, a literatura, os alunos, em todos os quadrinhos que desenha a minha imaginação, mesmo o analista mais hábil não encontrará o que se chama uma ideia geral, isto é, o deus do homem vivo.

E se não existe isso, quer dizer que não existe nada.

Esta reflexão nos remete à quarta regra, que diz respeito à totalidade e à pretensão de tudo saber. Em relação a isto, Adorno escreve que todo objeto "inclui em si infinitos aspectos cuja escolha só é decidida pela intenção do agente do conhecimento”. Ou seja, ele opõe a uma concepção segundo a qual "o objeto a ser estudado aparece plenamente nos conceitos que o abordam" um modo de pensar que leva em conta os aspectos subjetivos daquilo que é estudado - aspectos tais como intenção e consciência.

É por fazer uma análise de sua consciência que Nicolai percebe a distância que separa sua imagem daquela ligada a seu nome, o que o leva a concluir, nas últimas páginas da narrativa: "Foi somente pouco antes da morte, no ocaso dos meus dias, que notei em mim a ausência daquilo 
que os meus colegas filósofos denominam uma ideia geral”. Se o atributo da consciência possibilita ao homem ter noção da distância que o separa do mundo, mas também permite a integração de ambos, na novela de Tchekhov esta última possibilidade é negada a Nicolai.

\begin{abstract}
Em que se manifesta então o caráter excepcional da minha condição? Admitamos que sou mil vezes famoso, que sou um herói de quem a minha pátria se orgulha; em todos os jornais, publicam-se boletins sobre a minha doença, o correio me traz mensagens de simpatia de colegas, alunos e do público em geral, mas nada disso me impedirá de morrer numa cama alheia, angustiado e completamente só... Naturalmente, ninguém é culpado disso, mas, pecador que sou, não gosto do meu nome tão popular. Tenho a impressão de que fui enganado por ele. (TCHEKHOV, 1982, p. 295-6)
\end{abstract}

Cada vez mais inseguro, sem uma certeza que reunisse todas as suas ideias e pensamentos, Nicolai sente-se levado de modo indiferente a qualquer lado. Esta análise parece se confirmar com o que acontece a Kátia, personagem que funciona como contraponto do professor. Kátia é "vítima" da mesma tomada de consciência que o professor, sofrendo por isso do mesmo estado de espírito. Ambos se questionam. Desesperada, não sabendo o que fazer, ela pede ajuda a Nicolai. Frente à pergunta "O que devo fazer?", Nicolai só tem como resposta: "Pela minha consciência, Kátia: não sei...”. Assim, a novela termina sem que Nicolai forneça uma resposta para a jovem Kátia, porque ele mesmo é incapaz de descobrir respostas para as dúvidas que lhe perseguiam. Como se viu, este final em aberto, sem desfecho propriamente, reflete a postura de Tchekhov em relação ao trabalho do escritor, mas também sua própria incapacidade de alcançar conclusões para os problemas com que se deparava.

\title{
3. CONSIDERAÇÕES FINAIS
}

A pergunta “O que sei?" foi literalmente o mote de Montaigne, que, seguindo um hábito do Renascimento, mandou gravar esta frase em um dos lados de uma moeda. Do outro lado, figuravam os pratos de uma balança, em suspensão e equilibrados. A suspensão do juízo e a certeza de que nada é certo foram ideias que guiaram o ensaísta e, como vimos, também estão presentes na obra de Tchekhov - seja em perguntas formuladas abertamente em suas peças ou contos (que refletiam dúvidas expostas em sua correspondência), seja em procedimentos estilísticos como o inacabamento de seus textos. O ensaio evoca uma liberdade de espírito que foi identificada por Adorno como o motivo pelo qual ele 
provoca uma atitude defensiva na Alemanha. Parece ser justamente por isso - por expressar o sentimento de liberdade - que Tchekhov apresentava traços da escrita ensaística em sua obra. Porém, apesar de apresentarem traços estilísticos semelhantes, a escrita de Tchekhov se opõe à de Montaigne radicalmente em um ponto: se Tchekhov se afeiçoava a esta atitude, era talvez mais por ambicioná-la do que por sentir possuí-la. Enquanto podemos ver em Montaigne, apesar de seu pessimismo em relação a jamais alcançar alguma conclusão, uma alegria despreocupada que se conjuga sem conflito àquela primeira disposição, Tchekhov parece por vezes se angustiar com aquilo que ele identificava como uma falta por temer "levar o leitor para trás da luz". Para Virginia Woolf (1966, p. 109), tal atitude está presente em todos os escritores russos, em cada um dos quais "nós podemos discernir os traços de um santo, se consideramos como santidade a compaixão pelos sofrimentos dos outros, o amor por eles e o empenho em alcançar algum objetivo digno das mais altas demandas do espírito". Por isso, ela acrescenta, as conclusões da mente russa inevitavelmente são da maior tristeza; o que decorre, talvez, de sua irresolução. Ainda que as ponderações de Virginia Woolf possam ser generalizantes demais, acredito que elas devam ser lidas não no sentido de uma ideologia do caráter nacional russo, mas no sentido da percepção de valores comuns subjacentes à cultura - e, por extensão, à literatura - do país. É por esta via que as palavras seguintes, com que Woolf descreve a literatura russa como um todo, encaixam-se à perfeição na obra de Tchekhov:

É o sentido de que não há resposta, de que, se examinada, a vida apresenta pergunta após pergunta, as quais devem permanecer soando depois que a estória termina em uma interrogação desesperançada que nos enche de um profundo, e talvez de um ressentido, desespero.

O lamento por esta situação é entrevisto em algumas indicações fornecidas por Tchekhov, uma das quais é encontrada na própria novela. Após reclamar da situação da literatura russa, Nicolai escreve:

Não direi que os livros franceses sejam talentosos, inteligentes e nobres. Também eles não me satisfazem. Mas não são tão enfadonhos como os russos, e neles não raro se encontra o elemento principal da criação: o sentimento da liberdade individual, que não existe nos autores russos. (...) Premeditação, cautela, intencionalidade, mas não há liberdade nem coragem de escrever como se queira, e por conseguinte não há criação. (TCHEKHOV, 1982, p. 2812) 
Integrante da categoria "escritores russos", Tchekhov parece compartilhar deste sentimento de angústia que acometia o narrador (que, afinal, não se considerava digno sequer de ser lido, como já o indicava o título de sua história). Logo, mais do que a ausência de uma ideia geral que embasasse todo seu pensamento, o que parecia afligir Tchekhov era a ausência deste sentimento de liberdade, como se depreende de uma carta enviada a Alekséi Suvórin. Nesta passagem, Tchekhov (apud ANGELIDES, 1995, p. 131-2) fala sobre as qualidades necessárias para se escrever: "Em primeiro lugar, é necessário maturidade; em segundo lugar, é indispensável ter o sentimento de liberdade individual, e esse sentimento só começou a despertar em mim há pouco tempo". Na continuação desta carta, Tchekhov sugere um tema a Suvórin:

\begin{abstract}
Escreva, pois, um conto sobre um jovem, filho de servo, antigo vendedor de armazém, corista de igreja, ginasiano e depois universitário, que foi educado para respeitar a hierarquia, para beijar as mãos dos popes e para acatar as ideias alheias, que agradecia cada pedaço de pão, que foi muitas vezes açoitado, que ia às aulas sem galochas, que brigava, que torturava os animais, que gostava de almoçar na casa dos parentes ricos, que era hipócrita diante de Deus e dos homens, sem nenhuma necessidade, simplesmente por ter consciência de sua própria insignificância; escreva como esse jovem espreme, gota a gota, o escravo que tem dentro de si, e como ele, ao acordar numa bela manhã, sente que em suas veias já não corre o sangue do escravo, e sim o de um verdadeiro homem...
\end{abstract}

Assim, esta parece ter sido a questão perseguida por Tchekhov (ou a questão que o perseguiu): livrar-se das convenções, escrever livremente; enfim, encontrar aquele sentimento de liberdade individual que ele tão bem identificou nos escritores franceses e que buscou através de uma escrita que refletisse esses valores almejados - e que por isso se assemelhava à escrita ensaística. Procedendo deste modo, Tchekhov finalmente conseguiu espremer o escravo que tinha dentro de si e se tornar um verdadeiro escritor.

\title{
REFERÊNCIAS BIBLIOGRÁFICAS
}

ADORNO, Theodor. O Ensaio como Forma. IN: Notas sobre Literatura. Traduzido por Flávio R. Kothe. Rio de Janeiro: Tempo Brasileiro, 1973.

ANGELIDES, Sophia. A. P. Tchekhov: Cartas para uma Poética. São Paulo, Editora da Universidade de São Paulo, 1995. 
158 - Remate de Males 31.1-2

BARTHES, Roland. A Câmara Clara. Tradução de Júlio Castañon Guimarães. Rio de Janeiro, Nova Fronteira, 1984.

BURKE, Peter. Montaigne. Madrid: Alianza Editorial, 1985.

DESCARTES, Réné. Discurso do Método. Coleção Os Pensadores. São Paulo: Editora Nova Cultural, 1999.

LUKÁCS, Georg. "On the Nature and Form of the Essay”. IN: Soul and Form. Translator: Anne Bostock. Cambridge, The MIT Press, 1980.

MANN, Thomas. "Ensaio sobre Tchekhov”. IN: Ensaios. Tradução: Natan Robert Zins. São Paulo, Perspectiva, 1988.

MONTAIGNE, Michel de. Ensaios. Coleção Os Pensadores. Tradução de Sérgio Milliet. São Paulo: Abril Cultural, 1972.

POPKIN, Cathy. The pragmatics of insignificance: Chekhov, Zoshchenko, Gogol. Stanford: Stanford University Press, 1993.

SCHNAIDERMAN, Boris. "Posfácio". IN: TCHEKHOV, A. P. A dama do cachorrinho e outros contos. São Paulo: Ed. 34, 1999.

TCHEKHOV, Anton. As três irmãs; Contos. Traduções de Maria Jacintha, Boris Schnaiderman. São Paulo: Abril Cultural, 1982.

WOOLF, Virginia. “Modern Fiction”. IN: Collected Essays II. London: The Hogarth Press, 1966. 